\title{
Effect of Glutamate on Dendritic Growth in Embryonic Rat Motoneurons
}

\author{
Friedrich Metzger, Stefan Wiese, and Michael Sendtner \\ Klinische Forschergruppe Neuroregeneration, Department of Neurology, University of Würzburg, \\ 97080 Würzburg, Germany
}

\begin{abstract}
Glutamate is a major excitatory neurotransmitter for spinal motoneurons. We have investigated its effect on survival and neurite formation in cultures of highly enriched motoneurons from 15-d-old rat embryos. Whereas the survival of these neurons was not reduced by this treatment, a distinct and specific effect on dendrite outgrowth could be observed. Axon outgrowth was not affected by glutamate. Our data suggest that calcium influx via ionotropic AMPA/kainate (AMPA/KA) receptors is responsible for the regulation of dendrite outgrowth by excitatory neurotransmission. This was shown by the use of specific inhibitors for the different classes of glutamate receptors. The effect was reduced by continuous depolarization at 35
\end{abstract}

$\mathrm{mm} \mathrm{KCl}$ and by treatment with joro spider toxin (JSTX-3, $3 \mu \mathrm{M}$ ), a blocker of $\mathrm{Ca}^{2+}$-conducting AMPA receptors. Removal of glutamate after $5 \mathrm{~d}$ of culture led to increased dendrite growth during the following culture period, and delayed addition resulted in a reduction in the length of already existing dendrites. Our observation that the effect is dose-dependent and reversible reflects a potential physiological function of excitatory neurotransmission on dendrite growth and morphology during a developmental period when synaptic contacts from afferent neurons to motoneurons are made in the spinal cord.

Key words: glutamate; motoneurons; dendrite growth; development; AMPA/KA receptors; spinal cord
In most types of neurons within the CNS, the excitatory neurotransmitter glutamate activates several classes of specific receptors. The ionotropic NMDA and AMPA/kainate (AMPA/KA) glutamate receptors participate in the regulation of synaptic plasticity (Gu et al., 1996) (for review, see Collingridge and Singer, 1990; Gasic and Heinemann, 1991) as well as the formation of neuronal networks during development (Mayer and Westbrook, 1987), whereas the G-protein-coupled metabotropic glutamate receptors modulate synaptic transmission via second messengers like cAMP or inositol triphosphate (for review, see Schoepp et al., 1990). Besides its function in the transmission of physiological signals, glutamate can be toxic to neurons of the CNS. It has been hypothesized that developing motoneurons, which express relatively high levels of NMDA receptors, are particularly vulnerable to glutamate (Greensmith et al., 1994; Greensmith and Vrbová, 1996).

Important issues in the development of the nervous system are the regulation of process outgrowth to establish specific neuronal connections and the stabilization of newly formed synapses. Neurite outgrowth is dependent on several environmental or intrinsic factors, such as extracellular matrix, neurotrophic factors, or electrical activity. The involvement of neurotransmitters, such as glutamate, in the regulation of process outgrowth has been described for various neuronal populations. In fetal cat retinal ganglion cells, glutamate inhibited dendritic stratification selec-

\footnotetext{
Received Sept. 25, 1997; revised Dec. 11, 1997; accepted Dec. 15, 1997.

This work was supported by the Deutsche Forschungsgemeinschaft, Grant To61/ 8-1. We thank Dr. Jenny Gunnersen for helpful comments on this manuscript and Dr. Jessell (Columbia University, Hammer Health Sciences Center, New York) for providing the 40.2D6 hybridoma cells through the Developmental Studies Hybridoma Bank (Iowa City, IA).

Correspondence should be addressed to Dr. Michael Sendtner, Klinische Forschergruppe Neuroregeneration, Department of Neurology, University of Würzburg, Joseph-Schneider-Strasse 11, 97080 Würzburg, Germany.

Copyright (C) 1998 Society for Neuroscience $0270-6474 / 98 / 181735-08 \$ 05.00 / 0$
}

tively via non-NMDA receptors (Bodnarenko et al., 1995). In cortical brain slices from 14-d-old ferrets, BDNF, together with electrical activity, was found to induce dendrite growth in cortical pyramidal neurons (McAllister et al., 1996, 1997). In embryonic rat spinal cord explants the stimulation of electrical activity, which leads to enhanced excitatory neurotransmission, modulated the development of motoneuron resting potential and other specific properties (Xie and Ziskind-Conhaim, 1995). All together, these data suggest that contacting neurons play an important role in the regulation of dendrite growth. Such influences also can be observed in cell culture with isolated neurons. For example, morphological differentiation of Purkinje cells is stimulated by the presence of granule neurons in coculture (Baptista et al., 1994). If endogenous electrical activity in cultures of mouse cerebellar Purkinje cells is blocked by tetrodotoxin (TTX) or high $\mathrm{Mg}^{2+}$ treatment, then dendrite growth proceeds and differentiation of these cells apparently is impaired (Schilling et al., 1991). In cultures of cerebellar granule neurons, activation of the NMDA receptor inhibited axonal outgrowth (Baird et al., 1996), whereas in adult hippocampal pyramidal neurons low concentrations of glutamate $(1 \mu \mathrm{M})$ decreased dendrite growth (Mattson et al., 1988).

We have investigated the effect of glutamate on isolated motoneurons from 15-d-old rat embryos. We observed a specific modulation of dendritic, but not axonal, growth by glutamate. This plasticity effect of glutamate is mediated by AMPA/KA receptor activation. To our knowledge, these data demonstrate for the first time that glutamate influences the dendritic architecture of motoneurons, thus providing another example of activitydependent changes of dendritic structure in the CNS.

\section{MATERIALS AND METHODS}

Materials. MC192 hybridoma cells producing a monoclonal antibody against the low-affinity nerve growth factor receptor (p75) were obtained from the American Type Culture Collection (Rockville, MD), and 
40.2D6 cells producing the islet-1 antibody were obtained from the Developmental Studies Hybridoma Bank (Iowa City, IA). The growth factors brain-derived neurotrophic factor (BDNF) and glial-derived neurotrophic factor (GDNF) were from Preprotech (Frankfurt, Germany). Neurobasal medium, B27 supplement, glutamine, and trypsin were obtained from Life Technologies (Eggenstein, Germany). 6-Cyano-7nitroquinoxaline-2,3-dione (CNQX), D- $\gamma$-glutamylaminomethanesulfonic acid (GAMS), (+)- $\alpha$-methyl-4-carboxyphenylglycine (MCPG), dizocilpine maleate (MK-801), 1,2,3,4-tetrahydro-6-nitro-2,3-dioxobenzo[f]quinoxaline-7-sulfonamide (NBQX), NMDA, anti-mouse-Cy3 (goat), and anti-rabbit-Cy2 (goat) were purchased from RBI/Biotrend (Köln, Germany). JSTX-3 and TTX were obtained from Molecular Probes (Eugene, OR). Anti-microtubule-associated protein 2 (MAP2, mouse monoclonal) and anti-mouse $\operatorname{IgG}$ (sheep) were obtained from Boehringer Mannheim (Mannheim, Germany), goat and horse serum were obtained from Linaris (Wertheim, Germany), and anti-tau (rabbit) and the other chemicals were purchased from Sigma (Deisenhofen, Germany).

Rat embryonic motoneuron cultures. Cultures of spinal motoneurons from embryonic day 15 rats were prepared by an immunopanning technique as described (Hughes et al., 1993). Briefly, the ventral parts of the spinal cords were dissected and transferred to HBSS containing $10 \mu \mathrm{M}$ $\beta$-mercaptoethanol. The preparation time was kept to a minimum (usually $<30 \mathrm{~min})$. After treatment with trypsin $(0.05 \%, 15 \mathrm{~min})$, tissues were triturated with a fire-polished Pasteur pipette and passed through a nylon mesh (pore size, $100 \mu \mathrm{m}$ ) to remove connective tissue and cell clumps. The resulting suspension containing single cells was transferred to a polystyrene Petri dish (Falcon, Oxnard, CA) that had been precoated overnight with sheep anti-mouse $\operatorname{IgG}(1 \mu \mathrm{g} / \mathrm{ml})$ and subsequently for at least $3 \mathrm{hr}$ at room temperature with MC192 hybridoma supernatant (final antibody concentration, $1 \mu \mathrm{g} / \mathrm{ml}$ ). After incubation for $1 \mathrm{hr}$ at room temperature in such pretreated culture dishes, nonadherent cells were removed by gently washing with HBSS, and the motoneuron-enriched cell fraction was eluted by adding MC192 hybridoma supernatant. The motoneurons were plated at a density of 2000 cells $/ \mathrm{cm}^{2}$ in four-well culture dishes precoated with poly-ornithine and laminin as described (Arakawa et al., 1990). Cells were grown under serum-free conditions in Neurobasal medium supplemented with B27 and $500 \mu \mathrm{M}$ glutamine at $37^{\circ} \mathrm{C}$ in a humidified atmosphere with $5 \% \mathrm{CO}_{2}$. After $1 \mathrm{hr}$, neurotrophic factors and the various substances were added to the cultures and renewed with the medium at day 1 in culture and thereafter every $2 \mathrm{~d}$. The concentration of BDNF and GDNF used in this study was $10 \mathrm{ng} / \mathrm{ml}$, reflecting a saturating concentration. $\mathrm{EC}_{50}$ for $\mathrm{BDNF}$ was $9 \mathrm{pg} / \mathrm{ml}$, and for GDNF the $\mathrm{EC}_{50}$ was $80 \mathrm{pg} / \mathrm{ml}$. Maximal survival effects with BDNF and GDNF were observed at $10 \mathrm{ng} / \mathrm{ml}$ (data not shown).

Estimation of survival rates in motoneuron cultures. The initial cell number per well was determined $3 \mathrm{hr}$ after plating by phase-contrast microscopy (magnification, $125 \times$ ). Only phase-bright cells larger than 10 $\mu \mathrm{m}$ in diameter were included in the evaluation in predetermined fields corresponding to a total of $21 \%$ of the surface area of each well. We have chosen this technique because it allowed us to make the determination of cell numbers in the same cultures at different subsequent time points. Independent experiments in our lab have shown that the number of surviving neurons determined by counting phase-bright cells matches $>90 \%$ with the number determined by a life/dead kit (Molecular Probes, Leiden, The Netherlands). This kit is based on the cleavage of calcein AM in life cells and the staining of DNA by ethidium homodimer-1 in dead cells.

Surviving neurons were counted in the same fields at different time points for up to $7 \mathrm{~d}$ in culture, and the results are presented as the percentage of the originally plated cell number. To ensure that the cultures contained mainly motoneurons, we stained the cultures with the motoneuron-specific islet- 1 antibody. Cultures of $>90 \%$ motoneurons were obtained consistently.

In some experiments the motoneurons were cultured under depolarizing conditions in the presence of $35 \mathrm{~mm} \mathrm{KCl}$. Therefore, $3 \mathrm{hr}$ after plating, one-half of the medium was exchanged with isotonic $\mathrm{NaCl}$ solution containing $70 \mathrm{mM} \mathrm{KCl}$. Control cultures were treated with the same amount of isotonic $\mathrm{NaCl}$ solution. Living motoneurons were counted for up to $5 \mathrm{~d}$ in culture, as described above.

Counting of neurites. The number of neurites on each motoneuron was determined after 3 and $5 \mathrm{~d}$ in culture by phase-contrast microscopy. At a plating density of $2000 \mathrm{cells} / \mathrm{cm}^{2}$ most motoneurons grew without neurite contact to other cells. Single motoneurons were photographed (magnification, $250 \times$ ), and every neurite longer than $10 \mu \mathrm{m}$ was counted. In this

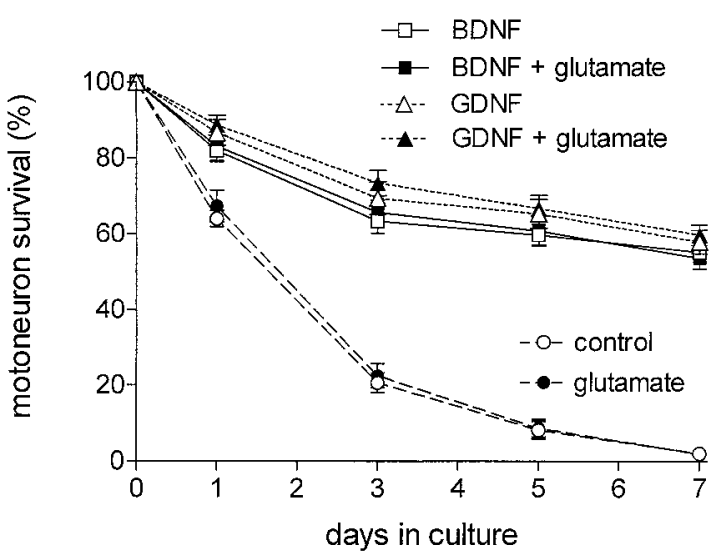

Figure 1. Survival of cultured embryonic rat motoneurons is not affected by glutamate. Motoneurons were prepared and cultured either without survival factors or in the presence of $10 \mathrm{ng} / \mathrm{ml}$ BDNF or GDNF. Survival rates were evaluated from cultures in the presence (filled symbols) or absence (open symbols) of $100 \mu \mathrm{M}$ glutamate over the total culture period. At the indicated time points, surviving motoneurons were counted in predetermined fields corresponding to $21 \%$ of the surface area of each well. These data represent the mean \pm SEM of eight observations from four independent experiments.

part of the study the differences between axons and dendrites were not taken into account.

Immunostaining of motoneurons for axonal and dendritic proteins. After 3 , 5, or $10 \mathrm{~d}$ in culture the axonal and dendritic processes of the motoneurons were distinguished by staining with specific markers. Briefly, cells were fixed for $30 \mathrm{~min}$ at $37^{\circ} \mathrm{C}$ with $4 \%$ paraformaldehyde. Subsequently, nonspecific binding sites were blocked, and cell membranes were permeabilized for 20 min with $10 \%$ goat serum and $0.01 \%$ Triton X-100. Primary antibodies were added for $30 \mathrm{~min}$ at $37^{\circ} \mathrm{C}$; then the dishes were washed twice, blocked again for $5 \mathrm{~min}$, and incubated for 20 $\min$ at $37^{\circ} \mathrm{C}$ with the secondary antibodies. After being washed, the cells were mounted with glycerol/PBS (1:1) and observed by fluorescence microscopy. The motoneurons were double-stained with monoclonal mouse anti-MAP2 $(5 \mu \mathrm{g} / \mathrm{ml})$ and rabbit anti-tau (1:200). MAP2 was visualized by goat anti-mouse-Cy3 $(5 \mu \mathrm{g} / \mathrm{ml})$, and tau was visualized with goat anti-rabbit-Cy2 $(10 \mu \mathrm{g} / \mathrm{ml})$.

Estimation of dendrite and axon length. The immunostained motoneurons were double-exposed under fluorescence light (magnification, $400 \times$ ) after 3, 5, and $10 \mathrm{~d}$ in culture. Then the mean length of all MAP2-positive and tau-positive processes per motoneuron was estimated from photographs by using a scaled overlay. To estimate the total process length of each motoneuron, we added the length of all dendrites or axons per cell.

Calculations and statistics. Values from independent experiments were pooled, and the results were expressed as the mean \pm SEM. Statistical significance of differences was assessed by ANOVA. Equal variances were tested by Bartlett's test. Differences between control and individual treatment groups were tested by Dunnett's multiple comparison test, using the GraphPad Prism software (San Diego, CA).

\section{RESULTS}

\section{Glutamate does not induce cell death in embryonic motoneuron cultures}

To investigate whether glutamate can induce cell death in cultured embryonic motoneurons, we isolated cells from 15-d-old rat embryos, which were enriched by immunopanning and cultured at a density of 2000 neurons $/ \mathrm{cm}^{2}$. Figure 1 illustrates the survival of motoneurons grown either with or without BDNF or GDNF (10 $\mathrm{ng} / \mathrm{ml}$ each) in the presence or absence of glutamate $(100 \mu \mathrm{M})$. In the absence of neurotrophic factors, only $14 \%$ of the originally plated motoneurons survived until day 5 in culture; survival decreased to $<5 \%$ by day 7 . Glutamate did not enhance cell death in such cultures in the absence of survival factors. 
Table 1. Glutamate reduces neurite outgrowth of embryonic rat motoneurons

\begin{tabular}{lll} 
& $\begin{array}{l}3 \mathrm{~d} \text { in } \\
\text { culture } \\
n\end{array}$ & $\begin{array}{l}5 \mathrm{~d} \text { in } \\
\text { culture } \\
n\end{array}$ \\
\hline BDNF & $3.20 \pm 0.12$ & $3.38 \pm 0.13$ \\
BDNF + glutamate & $2.16 \pm 0.09^{a}$ & $2.05 \pm 0.09^{a}$ \\
GDNF & $3.20 \pm 0.11$ & $3.45 \pm 0.14$ \\
GDNF + glutamate & $2.05 \pm 0.09^{a}$ & $2.11 \pm 0.08^{a}$
\end{tabular}

Motoneurons were cultured with $10 \mathrm{ng} / \mathrm{ml}$ BDNF or GDNF in the presence or absence of $100 \mu \mathrm{m}$ glutamate. All neurites longer than $10 \mu \mathrm{m}$ were counted after 3 and $5 \mathrm{~d}$ in culture by phase-contrast microscopy (magnification, 250×). Data represent mean \pm SEM of at least 119 single observations in four independent experiments.

${ }^{a} p<0.01$ versus respective value without glutamate as revealed by ANOVA and Dunnett's multiple comparison test.

The apparent lack of glutamate toxicity in neurotrophic factorsupported cultures could be attributable to a specific alteration of glutamate sensitivity by BDNF or GDNF. Such effects were observed in the neuronal cell lines PC-12 and HT-22, in which survival factors influenced glutamate-induced neurotoxicity (Schubert et al., 1992; Davis and Maher, 1994). Moreover, experiments with cultured retinal ganglion cells as well as other CNS neurons showed that activation of glutamate receptors was essential for the neurotrophic survival effect (Meyer-Franke et al., 1995; Nichol et al., 1995). Therefore, motoneurons were cultured in the presence of $2 \%$ horse serum, which supported their survival in the absence of specific neurotrophic factors. After $5 \mathrm{~d}$ in culture, $46.7 \pm 2.5 \%(n=3)$ of the motoneurons were still alive, and the presence of $100 \mu \mathrm{M}$ glutamate did not alter their survival significantly $(49.8 \pm 2.7 \% ; n=3)$.

When the cultures were supplemented with BDNF, $60 \pm 3 \%$ of the cells survived after $5 \mathrm{~d}$ in the absence and $61 \pm 4 \%$ in the presence of glutamate $(n=8)$. GDNF, another neurotrophic factor with specific survival-promoting activity in motoneuron cultures, supported $65 \pm 4 \%$ of the motoneurons in the absence and $67 \pm 4 \%$ in the presence of glutamate after $5 \mathrm{~d}$ in culture (Fig. $1 ; n=8$ ). Similar results were obtained after 1,3 , and $7 \mathrm{~d}$ in culture, suggesting that the addition of $100 \mu \mathrm{M}$ glutamate is not toxic to motoneuron cultures derived from 15-d-old rat embryos. Furthermore, the addition of NMDA (up to $10 \mu \mathrm{M}$ ), JSTX-3 (3 $\mu \mathrm{M})$, or TTX $(3 \mu \mathrm{M})$ did not alter motoneuron survival in the presence or absence of glutamate (data not shown). Depolarizing culture conditions $(35 \mathrm{~mm} \mathrm{KCl}$ ), which remove the NMDA receptor block by $\mathrm{Mg}^{2+}$ (Moriyoshi et al., 1991), led to slightly, but not significantly reduced motoneuron survival $(93 \pm 13 \%$ of control after $5 \mathrm{~d}$ in culture; $n=4)$. Again, glutamate did not reduce survival under these conditions $(89 \pm 12 \%$ of control after $5 \mathrm{~d}$ in culture; $n=4$ ).

The addition of glutamate to motoneuron cultures supported with both BDNF and GDNF also did not affect long-term survival significantly after a culture period of $10 \mathrm{~d}(n=3)$. At $10 \mathrm{~d}$ in culture, survival was $22.6 \pm 2.4 \%$ without glutamate and $22.2 \pm 2.6 \%$ with $100 \mu \mathrm{M}$ glutamate. Removal of glutamate after a period of $5 \mathrm{~d}$ as well as delayed addition of glutamate from days 5 to 10 led to similar survival rates $(24.4 \pm 2.7 \%$ and $21.0 \pm 2.2 \%$, respectively).

\section{Effect of glutamate on neurite number in cultured rat motoneurons}

The number of neurites per cell was determined (Table 1; Fig. 2) after 3 and $5 \mathrm{~d}$ in culture. Glutamate led to a highly significant
A

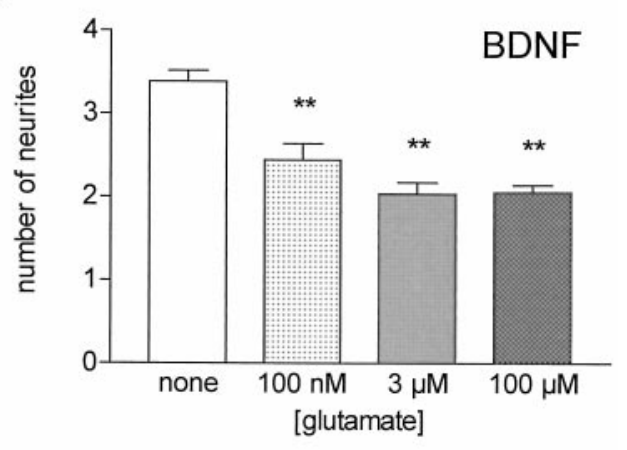

B

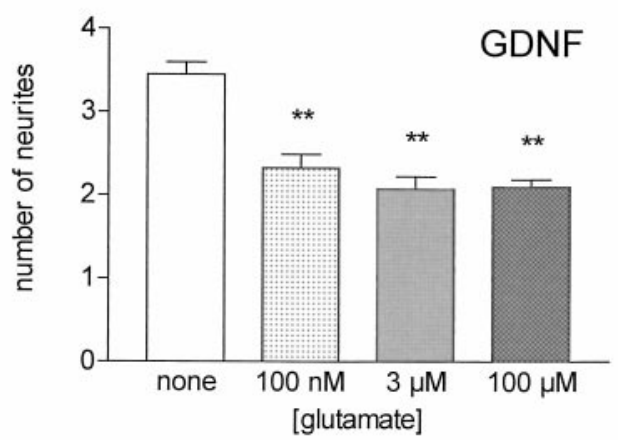

Figure 2. Glutamate reduces neurite number in embryonic rat motoneurons. Motoneurons were cultured with $10 \mathrm{ng} / \mathrm{ml} \operatorname{BDNF}(A)$ or $\operatorname{GDNF}(B)$ and increasing glutamate concentrations supplemented over the whole culture period. Neurites were counted after $5 \mathrm{~d}$ on phase-contrast micrographs (magnification, $250 \times$ ). These data represent the mean $\pm \mathrm{SEM}$ of at least 68 single observations from three to four independent experiments; asterisks indicate significant difference $(* *<<0.01)$ from the respective control (without glutamate) as revealed by ANOVA and Dunnett's multiple comparison test.

reduction in neurite numbers both in BDNF- and GDNFsupported cultures. This effect was already detectable after $3 \mathrm{~d}$. The average number of neurites in BDNF-supported cultures after $5 \mathrm{~d}$ was 2.05 neurites per motoneuron with $100 \mu \mathrm{M}$ glutamate and 3.38 neurites in the absence of glutamate. In GDNFtreated cultures, the number of dendrites was reduced similarly from 3.45 to 2.11 in the presence of $100 \mu \mathrm{M}$ glutamate (Table 1). Analysis of the concentration dependence of the glutamate effect $(0.1-100 \mu \mathrm{M})$ on neurite growth revealed a maximum effect at 3 $\mu \mathrm{M}$ glutamate, suggesting an $\mathrm{IC}_{50}$ value in the submicromolar range (Fig. 2).

\section{Characterization of the inhibitory glutamate effect on neurite growth with specific receptor antagonists}

To identify the glutamate receptor subtypes responsible for the effect on neurite growth, we added NBQX (3 $\mu \mathrm{M})$, a specific antagonist of AMPA receptors, CNQX $(10 \mu \mathrm{M})$, a blocker of both AMPA and KA receptors, GAMS (100 $\mu \mathrm{M})$, a preferential KA receptor blocker (Honoré et al., 1988; Zhou et al., 1993), and the selective NMDA receptor antagonist MK-801 (10 $\mu \mathrm{M}$; Moriyoshi et al., 1991) to our cultures. In addition, involvement of the metabotropic glutamate receptor, which was shown to sensitize AMPA/KA receptors by prolonged activation in rat dorsal horn spinal neurons (Cerne and Randic, 1992), was investigated by using the antagonist MCPG (200 $\mu \mathrm{M}$; Watkins and Collingridge, 1994). The effects of these compounds on glutamatetreated motoneurons after $5 \mathrm{~d}$ in culture are shown in Figure 3. 
A BDNF
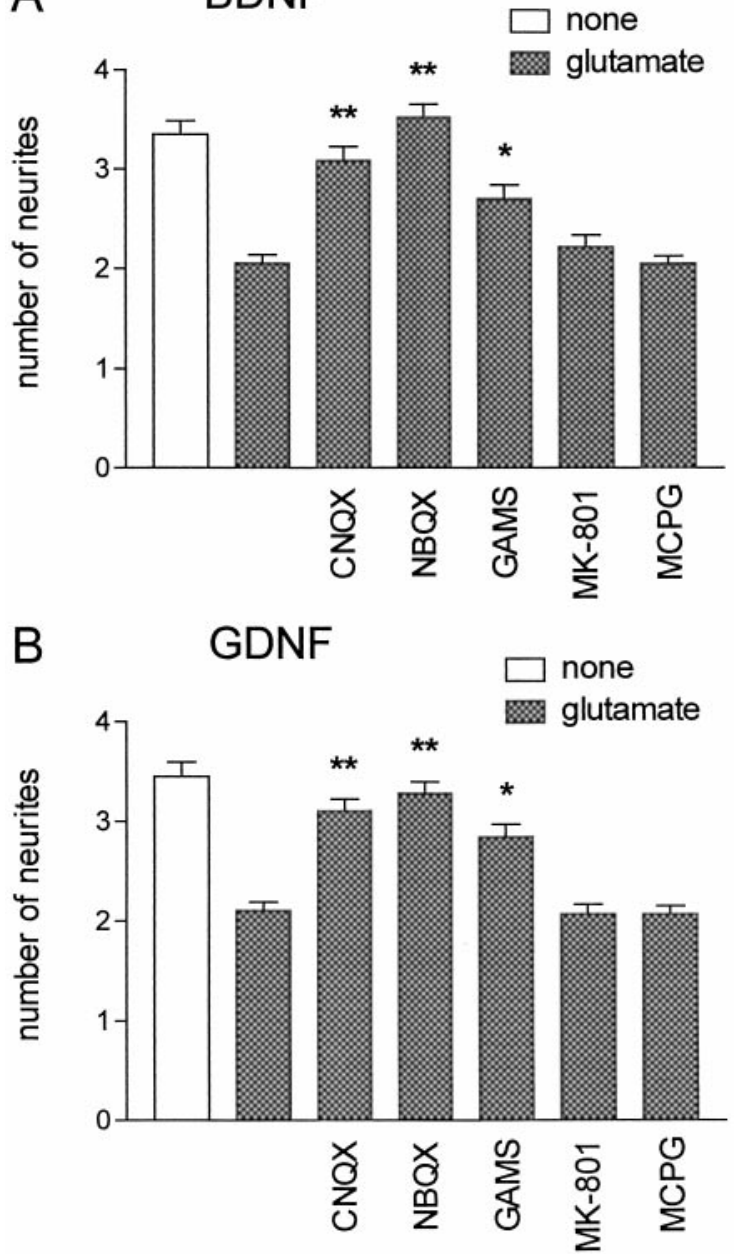

Figure 3. Glutamate affects neurite growth via AMPA and KA receptors. Motoneuron cultures were supplemented over the whole culture period with $10 \mathrm{ng} / \mathrm{ml} \operatorname{BDNF}(A)$ or $\operatorname{GDNF}(B)$ and $100 \mu \mathrm{M}$ glutamate (except control); additionally, the specific glutamate receptor antagonists CNQX $(10 \mu \mathrm{M})$, NBQX (3 $\mu \mathrm{M})$, GAMS $(100 \mu \mathrm{M})$, MK-801 $(10 \mu \mathrm{M})$, or MCPG $(200 \mu \mathrm{M})$ were applied. Neurites were counted after $5 \mathrm{~d}$ on phase-contrast micrographs (magnification, $250 \times$ ). These data represent the mean \pm SEM of at least 101 single observations from four independent experiments; asterisks indicate significant difference $(* p<0.05$; $* * p<0.01$ ) from control (presence of glutamate alone) as revealed by ANOVA and Dunnett's multiple comparison test.

All antagonists of AMPA and KA receptors abolished the glutamate effect on neurite growth in cultures supported by BDNF (Fig. $3 A$ ) or GDNF (Fig. 3B). In contrast, MK-801 and MCPG had no significant effect.

\section{Glutamate inhibits dendrite, but not axon growth}

To investigate whether glutamate selectively reduced growth of either axonal or dendritic processes, we double-stained the motoneurons with antibodies for axonal tau and dendritic MAP2. Figure 4 shows typical stained cells grown with BDNF for 3 or $5 \mathrm{~d}$ either in the absence (Fig. $4 A, C$ ) or presence of $100 \mu \mathrm{M}$ glutamate (Fig. $4 B, D$ ). The quantitative evaluation of these changes is presented in Table 2. Glutamate treatment selectively inhibited dendrite growth, because the estimated parameters for taupositive axons did not differ between treated and untreated cultures. More than $80 \%$ of the motoneurons contained only one tau-stained axon, and length and number were unchanged by glutamate (Table 2). On the other hand, glutamate treatment decreased both the number and length of MAP2-positive dendrites. The mean number was reduced significantly by glutamate treatment from 2.46 to 1.20 dendrites per cell, and the mean length of dendritic processes decreased from 36 to $26 \mu \mathrm{m}$ (Table 2).

\section{The modulation of dendrite growth by glutamate is dependent on $\mathrm{Ca}^{2+}$ influx}

As a next step, we investigated whether $\mathrm{Ca}^{2+}$ influx or depolarization via $\mathrm{Na}^{+}$channels plays a role in the effect of glutamate on motoneuron dendrite growth. Therefore, motoneurons were cultured in the presence of BDNF for $5 \mathrm{~d}$ under depolarizing conditions ( $35 \mathrm{~mm} \mathrm{KCl)}$. Other cultures were treated with TTX (3 $\mu \mathrm{M})$, a blocker of voltage-dependent $\mathrm{Na}^{+}$channels. To block selectively the $\mathrm{Ca}^{2+}$-conducting AMPA receptors, we applied JSTX-3 (3 $\mu$ m; Blaschke et al., 1993; Iino et al., 1996). Continuous depolarization by $35 \mathrm{~mm} \mathrm{KCl}$ was expected to elevate intracellular $\mathrm{Ca}^{2+}$. This treatment did not reduce the number of dendrites, but it led to a partial reduction in their individual length (average length was $30 \mu \mathrm{m}$, as compared with $36 \mu \mathrm{m}$ in control and $26 \mu \mathrm{m}$ in glutamate-treated cultures). Interestingly, depolarization also exerted a strong reduction in axon length $(94 \mu \mathrm{m}$, as compared with $136 \mu \mathrm{m}$ in control cultures) that was not seen in glutamatetreated cultures. This indicates that depolarization by $\mathrm{KCl}$, but not by glutamate, can reduce axon outgrowth significantly. Thus the signals that regulate dendrite and axon growth in isolated motoneurons appear to be different. Treatment with JSTX-3 slightly reduced both dendrite number and length, whereas axon growth was not changed (Table 2). The reduction of total dendrite length by glutamate was nearly abolished by depolarization, whereas blockade of neuronal activity by TTX had no influence on this effect (Table 2; Fig. 5). In contrast, blockade of $\mathrm{Ca}^{2+}$ influx via AMPA receptors by JSTX-3 provided a condition under which glutamate could not lead to any further effect on dendrite number and length (Table 2; Fig. 5).

\section{The inhibition of dendrite growth by glutamate is reversible}

A further point of investigation was the reversibility and plasticity of the glutamate effect on process outgrowth. Therefore, motoneurons were cultured in the presence of both BDNF and GDNF to enhance long-term survival for up to $10 \mathrm{~d}$. Glutamate $(100 \mu \mathrm{M})$ was added either from days 1 to 5 or from days 5 to 10 in culture. The motoneurons surviving after $10 \mathrm{~d}$ were doublestained for MAP2/tau, and the lengths of dendrites and axons were determined differentially. At $5 \mathrm{~d}$ the motoneurons showed, on average, $1.03 \pm 0.03$ axons (length, $136 \pm 5 \mu \mathrm{m}$ ) and $2.46 \pm$ 0.13 dendrites (length, $36 \pm 1 \mu \mathrm{m}$ ). At $10 \mathrm{~d}$, on average, $1.12 \pm$ 0.05 axons (length, $160 \pm 7 \mu \mathrm{m}$ ) and $2.18 \pm 0.15$ dendrites (length, $37 \pm 1 \mu \mathrm{m}$ ) were observed. These values did not differ significantly from those obtained after $5 \mathrm{~d}$ in culture. The addition of glutamate from days 5 to 10 in culture strongly reduced total dendrite length (Fig. 6) to levels lower than at 5 d, suggesting that glutamate addition led to an involution of dendrites that had already grown out significantly at $5 \mathrm{~d}$. At $10 \mathrm{~d}$, the dendrite length in these cultures was comparable to those motoneurons maintained with glutamate over the whole culture period. On the other hand, removal of glutamate after $5 \mathrm{~d}$ led to partial recovery by an increased growth of dendrites during the following culture period (Fig. 6). Axon growth remained totally unaffected by the removal or addition of glutamate (data not shown). 

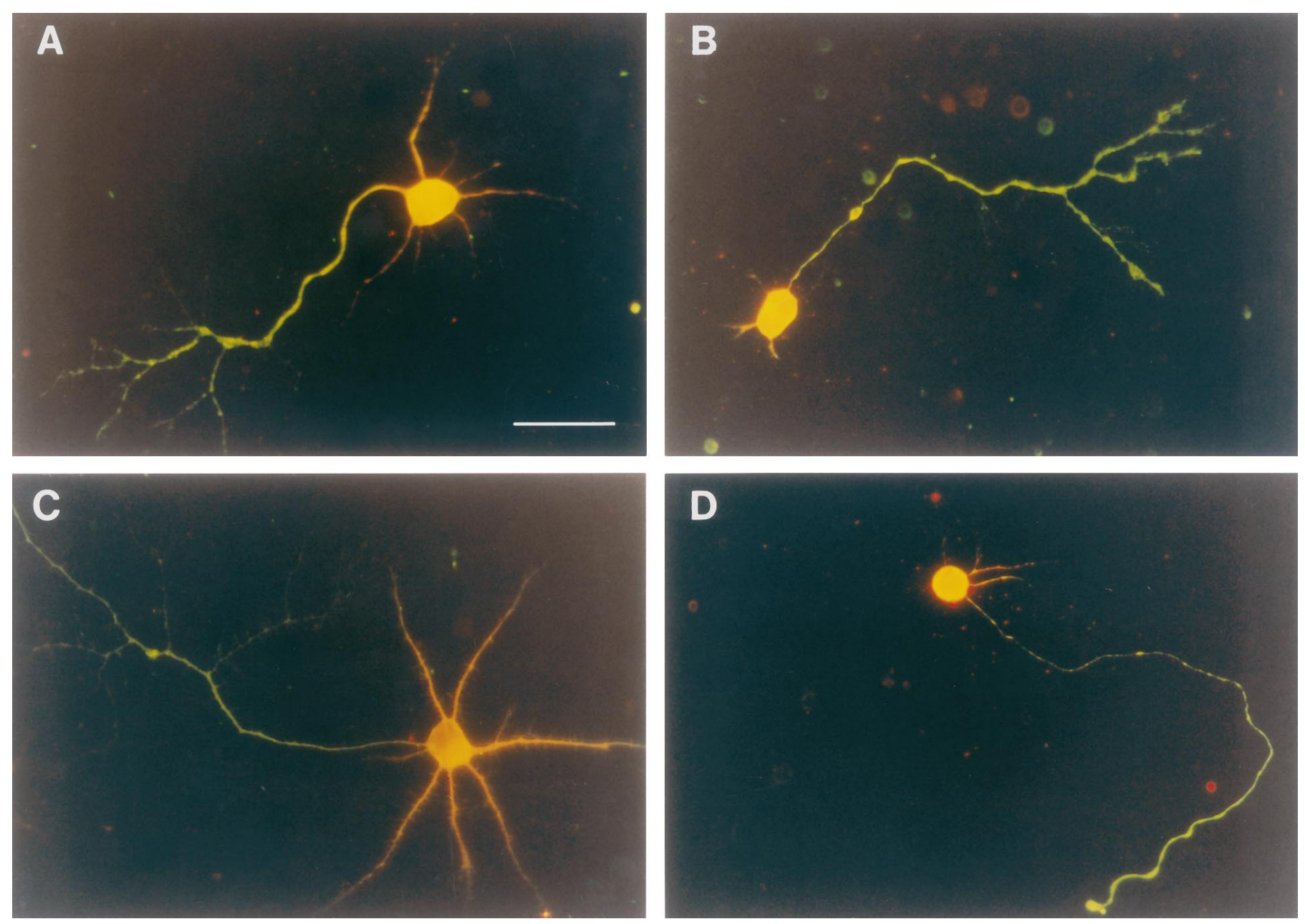

Figure 4. Effect of glutamate on dendrite growth in embryonic rat motoneurons. Motoneurons were cultured for $3 \mathrm{~d}(A$ and $B)$ or $5 \mathrm{~d}(C$ and $D)$ with $10 \mathrm{ng} / \mathrm{ml} \mathrm{BDNF}$ in the presence or absence of $100 \mu \mathrm{M}$ glutamate. Then the cells were fixed and stained for axonal tau (green processes) and dendritic MAP2 protein (orange processes), as described in Materials and Methods. Shown is a motoneuron cultured for $3 \mathrm{~d}$ without $(A)$ or with $(B)$ glutamate. $C$, Control. $D$, Glutamate-treated motoneuron after $5 \mathrm{~d}$ in culture. Scale bar, $50 \mu \mathrm{m}$.

\section{Table 2. Characterization of the effect of glutamate on growth of axons and dendrites in embryonic rat} motoneurons

\begin{tabular}{|c|c|c|c|c|}
\hline & \multicolumn{2}{|c|}{ MAP2-positive processes } & \multicolumn{2}{|c|}{ Tau-positive processes } \\
\hline & $n$ & Length $(\mu \mathrm{m})$ & $n$ & Length $(\mu \mathrm{m})$ \\
\hline Control & $2.46 \pm 0.13$ & $36 \pm 1$ & $1.03 \pm 0.03$ & $136 \pm 5$ \\
\hline Control + glutamate & $1.20 \pm 0.10^{a}$ & $26 \pm 1$ & $1.07 \pm 0.03$ & $149 \pm 5$ \\
\hline Depolarized & $2.40 \pm 0.14$ & $30 \pm 1$ & $1.02 \pm 0.04$ & $94 \pm 4^{a}$ \\
\hline Depolarized + glutamate & $2.28 \pm 0.12$ & $30 \pm 1$ & $1.08 \pm 0.04$ & $94 \pm 4$ \\
\hline TTX $(3 \mu \mathrm{M})$ & $2.01 \pm 0.16$ & $32 \pm 1$ & $1.02 \pm 0.04$ & $129 \pm 4$ \\
\hline TTX $(3 \mu \mathrm{M})+$ glutamate & $1.11 \pm 0.12^{a}$ & $25 \pm 1$ & $1.08 \pm 0.04$ & $130 \pm 3$ \\
\hline JSTX-3 (3 $\mu \mathrm{M})$ & $1.75 \pm 0.15$ & $29 \pm 1$ & $1.08 \pm 0.05$ & $119 \pm 4$ \\
\hline JSTX-3 $(3 \mu \mathrm{M})+$ glutamate & $1.74 \pm 0.14$ & $27 \pm 1$ & $1.05 \pm 0.03$ & $127 \pm 4$ \\
\hline
\end{tabular}

Motoneurons were cultured in the presence of BDNF with or without glutamate $(100 \mu \mathrm{M})$ under the indicated conditions, and the motoneurons were doublestained after $5 \mathrm{~d}$. The length (in $\mu \mathrm{m}$ ) of MAP2- and tau-positive processes was measured with a scaled overlay. Data represent mean \pm SEM of at least 77 single observations in three to four independent experiments.

${ }^{a} p<0.01$ versus control as revealed by ANOVA and Dunnett's multiple comparison test.

\section{DISCUSSION}

We have investigated the effect of glutamate on survival and outgrowth of dendrites and axons in cultured embryonic rat motoneurons. Our results indicate that glutamate does not induce cell death at a concentration $(100 \mu \mathrm{M})$ that saturates all types of ionotropic receptors. However, glutamate specifically reduces dendrite outgrowth. This reduction was similar in motoneuron cultures grown in the presence of BDNF or GDNF and was at 


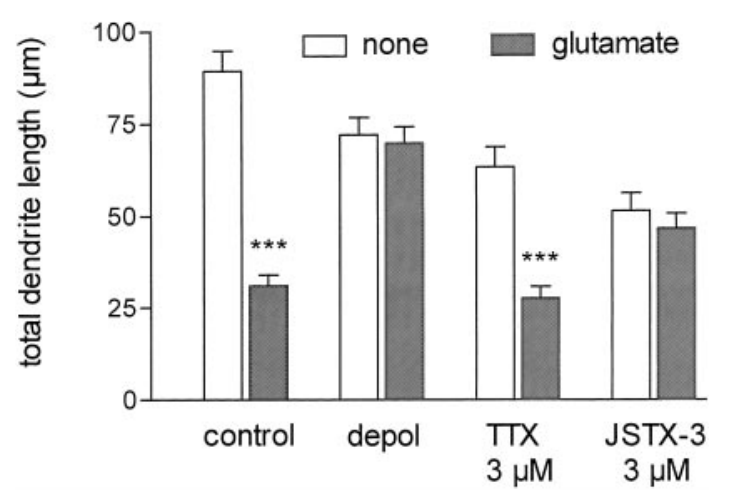

Figure 5. The effect of glutamate on dendrite growth is abolished by depolarization and JSTX-3. Motoneuron cultures supplemented with 10 $\mathrm{ng} / \mathrm{ml}$ BDNF were grown with or without $100 \mu \mathrm{M}$ glutamate; additionally, the indicated conditions (depolarization, depol) or substances were applied. After $5 \mathrm{~d}$, the cells were fixed and stained for tau and MAP2, and the total dendrite length was estimated from fluorescence micrographs (magnification, $400 \times$ ). These data represent the mean \pm SEM of at least 91 single observations from three to four independent experiments; asterisks indicate significant difference $(* * *<0.01)$ from control without glutamate as revealed by ANOVA and Dunnett's multiple comparison test.

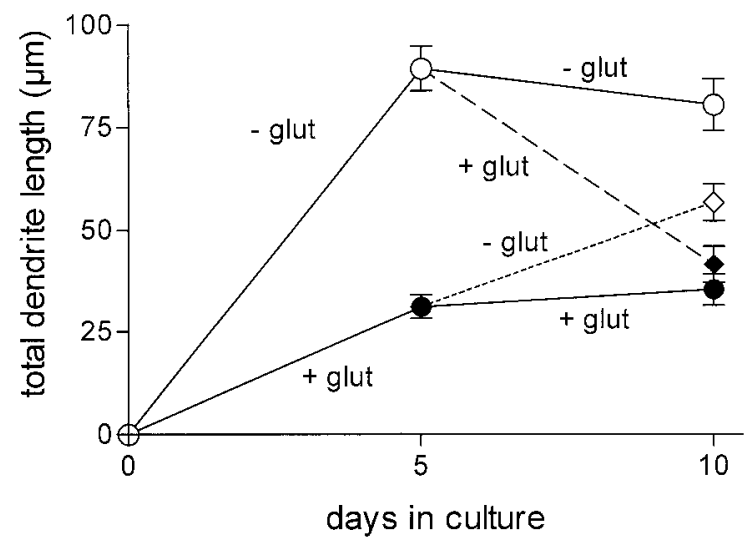

Figure 6. Plasticity of the glutamate effect on dendrite growth. Motoneuron cultures were supplemented with $10 \mathrm{ng} / \mathrm{ml}$ of both BDNF and GDNF for the whole culture period. Glutamate $(+g l u t ; 100 \mu \mathrm{M})$ was applied over a $10 \mathrm{~d}$ culture period, added, or removed after $5 \mathrm{~d}$. After $10 \mathrm{~d}$, the cells were fixed and stained for tau and MAP2, and the total dendrite length was estimated from fluorescence micrographs (magnification, 400×). These data represent the mean \pm SEM of at least 77 single observations from three independent experiments.

least partially reversible when glutamate was removed. Our data suggest that the modulation of dendrite outgrowth occurred via activation of AMPA/KA receptors, whereas NMDA and metabotropic receptors were not involved. Thus AMPA/KA receptors could regulate highly specific aspects of motoneuron development, in particular during a period when synaptic connections between proprioceptive sensory nerve fibers and motoneurons are made in the embryonic spinal cord.

\section{Glutamate is not toxic to embryonic motoneurons}

Glutamate toxicity at high concentrations $\left(\mathrm{IC}_{50} \sim 300 \mu \mathrm{M}\right)$ has been reported in studies that used motoneuron-enriched cultures from 12- to 14-d-old rat embryos (Estevez et al., 1995). In organotypic slice cultures derived from 8-d-old postnatal rats, slow motoneuron degeneration in the presence of agonists of AMPA/KA receptors or inhibitors of glutamate transporters has been demonstrated (Rothstein et al., 1993, 1996). Other studies showed that embryonic motoneurons express NMDA receptors at levels higher than adult motoneurons (Kalb et al., 1992), and electrophysiological analysis in rat spinal cord preparations from embryonic days 15 to 21 indicated that the NMDA receptors on the motoneurons are functional (Ziskind-Conhaim, 1990). Involvement of NMDA receptors in lesion-induced motoneuron death has been reported (Greensmith et al., 1994). Therefore, glutamate toxicity in motoneurons via NMDA after nerve injury as well as non-NMDA receptors has been inferred (Greensmith and Vrbová, 1996). Our data suggest that isolated motoneurons are not susceptible to glutamate toxicity, neither at embryonic day 15 when they express functional NMDA receptors nor at periods up to $10 \mathrm{~d}$ in culture during which they grow out axons and dendrites. Therefore, we conclude that highly enriched isolated motoneurons are much more resistant to glutamate excitotoxicity than other neuronal cell types, such as hippocampal neurons.

\section{Glutamate inhibits dendrite outgrowth in isolated motoneurons}

Motoneurons treated with glutamate show a concentrationdependent decrease in neurite number (Table 2). This effect was maximal at $3 \mu \mathrm{M}$ (see Fig. 2), suggesting that specific signaling via ionotropic glutamate receptors is involved. Using the axon- and dendrite-specific markers tau and MAP2, we could show that glutamate treatment does not alter the number and length of axons (Table 2; Fig. 4) but selectively inhibits dendrite growth. Very similar results have been described for subtoxic glutamate concentrations in cultures of adult hippocampal pyramidal neurons (Mattson et al., 1988) or fetal cat retinal ganglion cells (Bodnarenko et al., 1995) in which glutamate did not affect viability but inhibited dendritic stratification in the retina. These studies suggested an effect of glutamate on the differentiation of developing neurons via NMDA receptors. Baird et al. (1996) advanced the hypothesis that NMDA receptor activation in cerebellar granule neurons can modulate axonal outgrowth after contact with primary afferents. In contrast, the motoneurons used in our study showed no change in either number or length of axons by glutamate after 5 or $10 \mathrm{~d}$.

The outgrowth of processes from cultured motoneurons is very fast until day 5 in culture, but then it slows down dramatically. Little increase of axon length and virtually no further growth of dendrites could be observed during the following $5 \mathrm{~d}$ in culture. Compensatory increased growth could be observed from days 5 to 10 in culture (see Fig. 6) only when glutamate was added transiently from days 1 to 5 . The addition of glutamate to the motoneurons at a time when their dendrites had reached maximal length (day 5) could induce involution during the following culture period. This indicates that the effect of glutamate on dendrite growth is reversible and that glutamate thus modulates the dendritic architecture of motoneurons during development.

\section{The effect of glutamate on dendrite growth is mediated by AMPA/KA receptors}

The inhibition of dendritic outgrowth by glutamate was abolished specifically by antagonists of AMPA and KA receptors, but not by blockers of NMDA or metabotropic receptors (see Fig. 3). Using JSTX-3 (Blaschke et al., 1993), we could show that $\mathrm{Ca}^{2+}$ influx is involved. Moreover, depolarization by elevated $\mathrm{K}^{+}$in the culture medium reduces the effect, probably by desensitization of glutamate receptors or by the elevation of intracellular $\mathrm{Ca}^{2+}$ in the cytosol of motoneurons or by both mechanisms. 
Interestingly, even these conditions have only very little effect on motoneuron survival. Also, the addition of TTX does not block the glutamate effect on dendrite growth. This provides another proof that classical NMDA receptors in which the $\mathrm{Mg}^{2+}$ block is removed by depolarization probably are not involved in the observed effects. Theoretically, we cannot exclude the possibility that NMDA or AMPA receptors or downstream effector systems are desensitized progressively by depolarization or extensive glutamate treatment (Imredy and Yue, 1994; Ballerini et al., 1995). However, this is unlikely, at least for AMPA receptors, because the inhibition of dendrite growth appears to be strong (Table 2) and is maintained over periods of at least $10 \mathrm{~d}$ in culture.

$\mathrm{Ca}^{2+}$-conducting AMPA/KA receptors have been reported to trigger long-term effects in dorsal horn spinal neurons $(\mathrm{Gu}$ et al., 1996), but their molecular composition remains to be defined. Motoneurons express the subunits GluR-B and GluR-D at significant levels, mostly the flip isoform. Also, high levels of GluR-C, both in flip and flop isoform, are detectable (Tölle et al., 1995). Because these subunits are part of $\mathrm{Ca}^{2+}$. conducting functional AMPA receptors, it is highly suggestive that such receptors exist on motoneurons and that they are responsible for mediating the glutamate effects on dendrite growth observed in our study.

At motoneuron dendrites, glutamate is provided physiologically by primary sensory afferents from the dorsal root ganglia (Furuyama et al., 1993). During development of rat embryos the entry of glutamatergic afferents into the gray matter of the spinal cord can be observed from embryonic day 15 on, and the initial contacts between afferent projections from the dorsal root ganglia and motoneurons are formed at embryonic day 16 (ZiskindConhaim, 1990). This time course matches very well with the developmental stage of the embryonic motoneurons used in our experiments. The presence of glutamate in our in vitro system thus could mimic a glutamatergic input from proprioceptive neurons. The postsynaptic ionotropic glutamate receptors then mediate this regulatory signal for dendrite growth in motoneurons. This process could contribute to the determination of neuronal connections in the developing spinal cord.

The establishment and stabilization of synapses plays an important role for the morphological maturation of the nervous system. Therefore, the contribution of neurotransmitters in this process is of special interest. Glutamate has been described to trigger a variety of cellular responses associated with such changes; some of them are mediated by an increase in intracellular $\mathrm{Ca}^{2+}$. For example, postsynaptic phosphorylation of microtubule-associated proteins, such as MAP2 in hippocampal slices, is influenced by changes in intracellular $\mathrm{Ca}^{2+}$, mediated via metabotropic and NMDA-type glutamate receptors (Quinlan and Halpain, 1996). The local and temporal regulation of MAP protein phosphorylation in response to glutamate could modulate microtubule stability and bundling during neuritogenesis (Ávila et al., 1994), thus determining dendrite arborization (DíezGuerra and Ávila, 1993). MAP2 is present only in dendrites and cell somata, which matches the distribution of $\mathrm{Ca}^{2+}$-conducting GluR-C and GluR-D subunits in motoneurons (Furuyama et al., 1993). Therefore, we hypothesize that the activity-dependent regulation of MAP2 phosphorylation via glutamate receptors may trigger the morphological changes observed in developing motoneurons.

\section{REFERENCES}

Arakawa Y, Sendtner M, Thoenen H (1990) Survival effect of ciliary neurotrophic factor (CNTF) on chick embryonic motoneurons in culture: comparison with other neurotrophic factors and cytokines. J Neurosci 10:3507-3515.

Ávila J, Dominguez J, Díaz-Nido J (1994) Regulation of microtubule dynamics by microtubule-associated protein expression and phosphorylation during neuronal development. Int J Dev Biol 38:13-25.

Baird DH, Trenkner E, Mason CA (1996) Arrest of afferent axon extension by target neurons in vitro is regulated by the NMDA receptor. J Neurosci 16:2642-2648.

Ballerini L, Bracci E, Nistri A (1995) Desensitization of AMPA receptors limits the amplitude of EPSPs and the excitability of motoneurons of the rat isolated spinal cord. Eur J Neurosci 7:1229-1234.

Baptista CA, Hatten ME, Blazeski R, Mason CA (1994) Cell-cell interactions influence survival and differentiation of purified Purkinje cells in vitro. Neuron 12:243-260.

Blaschke M, Keller BU, Rivosecchi R, Hollmann M, Heinemann S, Konnerth A (1993) A single amino acid determines the subunitspecific spider toxin block of $\alpha$-amino-3-hydroxy-5-methylisoxazole-4propionate/kainate receptor channels. Proc Natl Acad Sci USA 90:6528-6532.

Bodnarenko SR, Jeyarasasingam G, Chalupa LM (1995) Development and regulation of dendritic stratification in retinal ganglion cells by glutamate-mediated afferent activity. J Neurosci 15:7037-7045.

Cerne R, Randic M (1992) Modulation of AMPA and NMDA responses in rat spinal dorsal horn neurons by trans-1-aminocyclopentane-1,3dicarboxylic acid. Neurosci Lett 144:180-184.

Collingridge GL, Singer W (1990) Excitatory amino acid receptors and synaptic plasticity. Trends Pharmacol Sci 11:290-296.

Davis JB, Maher P (1994) Protein kinase C activation inhibits glutamate-induced cytotoxicity in a neuronal cell line. Brain Res 652:169-173.

Díez-Guerra FJ, Ávila J (1993) MAP2 phosphorylation parallels dendrite arborization in hippocampal neurons in culture. NeuroReport 4:419-422.

Estevez AG, Stutzmann JM, Barbeito L (1995) Protective effect of riluzole on excitatory amino acid-mediated neurotoxicity in motoneuronenriched cultures. Eur J Pharmacol 280:47-53.

Furuyama T, Kiyama H, Sato K, Park HT, Maeno H, Takagi H, Tohyama M (1993) Region-specific expression of subunits of ionotropic glutamate receptors (AMPA-type, KA-type, and NMDA receptors) in the rat spinal cord with special reference to nociception. Mol Brain Res 18:141-151.

Gasic GP, Heinemann SF (1991) Receptors coupled to ionic channels: the glutamate receptor family. Curr Opin Neurobiol 1:20-26.

Greensmith L, Vrbová G (1996) Motoneuron survival: a functional approach. Trends Neurosci 19:450-455.

Greensmith L, Mentis GZ, Vrbová G (1994) Blockade of $N$-methyl-Daspartate receptors by MK-801 (dizocilpine maleate) rescues motoneurons in developing rats. Dev Brain Res 81:162-170.

Gu JG, Albuquerque C, Lee CJ, MacDermott AB (1996) Synaptic strengthening through activation of $\mathrm{Ca}^{2+}$-permeable AMPA receptors. Nature 381:793-796.

Honoré T, Davies SN, Drejer J, Fletcher EJ, Jacobsen P, Lodge D, Nielsen FE (1988) Quinoxalinediones: potent competitive nonNMDA glutamate receptor antagonists. Science 241:701-703.

Hughes RA, Sendtner M, Thoenen H (1993) Members of several gene families influence survival of rat motoneurons in vitro and in vivo. J Neurosci Res 36:663-671.

Iino M, Koike M, Isa T, Osawa S (1996) Voltage-dependent blockage of $\mathrm{Ca}^{2+}$-permeable AMPA receptors by joro spider toxin in cultured hippocampal neurones. J Physiol (Lond) 496:431-437.

Imredy JP, Yue DT (1994) Mechanism of $\mathrm{Ca}^{2+}$-sensitive inactivation of L-type $\mathrm{Ca}^{2+}$ channels. Neuron 12:1301-1318.

Kalb RG, Lidow MS, Halsted MJ, Hockfield S (1992) $N$-methyl-Daspartate receptors are transiently expressed in the developing spinal cord ventral horn. Proc Natl Acad Sci USA 89:8502-8506.

Mattson MP, Dou P, Kater SB (1988) Outgrowth-regulating actions of glutamate in isolated hippocampal pyramidal neurons. J Neurosci 8:2087-2100.

Mayer ML, Westbrook GL (1987) The physiology of excitatory amino acids in the vertebrate central nervous system. Prog Neurobiol 28:197-276. 
McAllister AK, Katz LC, Lo DC (1996) Neurotrophin regulation of cortical dendritic growth requires activity. Neuron 17:1057-1064.

McAllister AK, Katz LC, Lo DC (1997) Opposing roles for endogenous $\mathrm{BDNF}$ and NT-3 in regulating cortical dendritic growth. Neuron 18:756-778.

Meyer-Franke A, Kaplan MR, Pfrieger FW, Barres BA (1995) Characterization of the signaling interactions that promote the survival and growth of developing retinal ganglion cells in culture. Neuron 15:805-819.

Moriyoshi K, Masu M, Ishii T, Shigemoto R, Mizuno N, Nakanishi S (1991) Molecular cloning and characterization of the rat NMDA receptor. Nature 354:31-37.

Nichol KA, Schulz MW, Bennett MR (1995) Nitric oxide-mediated death of cultured neonatal retinal ganglion cells: neuroprotective properties of glutamate and chondroitin sulfate proteoglycan. Brain Res 697:1-16.

Quinlan EM, Halpain S (1996) Postsynaptic mechanisms for bidirectional control of MAP2 phosphorylation by glutamate receptors. Neuron 16:257-268.

Rothstein JD, Jin L, Dykes-Hoberg M, Kuncl RW (1993) Chronic inhibition of glutamate uptake produces a model of slow neurotoxicity. Proc Natl Acad Sci USA 90:6591-6595.

Rothstein JD, Dykes-Hoberg M, Pardo CA, Bristol LA, Jin L, Kuncl RW, Kanai Y, Hediger MA, Wang Y, Schielke JP, Welty DF (1996) Knockout of glutamate transporters reveals a major role for astroglial transport in excitotoxicity and clearance of glutamate. Neuron $16: 675-686$.
Schilling K, Dickinson MH, Connor JA, Morgan JI (1991) Electrical activity in cerebellar cultures determines Purkinje cell dendritic growth patterns. Neuron 7:891-902.

Schoepp D, Bockaert J, Sladezcek F (1990) Pharmacological and functional characteristics of metabotropic excitatory amino acid receptors. Trends Pharmacol Sci 11:508-515.

Schubert D, Kimura H, Maher P (1992) Growth factors and vitamin E modify neuronal glutamate toxicity. Proc Natl Acad Sci USA 89:8264-8267.

Tölle TR, Berthele A, Zieglgänsberger W, Seeburg PH, Wisden W (1995) Flip and flop variants of AMPA receptors in the rat lumbar spinal cord. Eur J Neurosci 7:1414-1419.

Watkins JC, Collingridge GL (1994) Phenylglycine derivatives as antagonists of metabotropic glutamate receptors. Trends Pharmacol Sci 15:333-342.

Xie H, Ziskind-Conhaim L (1995) Blocking $\mathrm{Ca}^{2+}$-dependent synaptic release delays motoneuron differentiation in the rat spinal cord. J Neurosci 15:5900-5911.

Zhou N, Hammerland LG, Parks TN (1993) Gamma-Dglutamylaminomethyl sulfonic acid (GAMS) distinguishes kainic acidfrom AMPA-induced responses in Xenopus oocytes expressing chick brain glutamate receptors. Neuropharmacology 32:767-775.

Ziskind-Conhaim L (1990) NMDA receptors mediate poly- and monosynaptic potentials in motoneurons of rat embryos. J Neurosci 10: $125-135$. 